\title{
Review of the Genus Andropogon (Poaceae: Andropogoneae) in America Based on Cytogenetic Studies
}

\author{
Nicolás Nagahama ${ }^{1}$ and Guillermo A. Norrmann ${ }^{2}$ \\ ${ }^{1}$ Instituto Multidisciplinario de Biología Vegetal (IMBIV-CONICET), C.C. 495, 5000 Córdoba, Argentina \\ ${ }^{2}$ Facultad de Ciencias Agrarias (FCA),UNNE y Instituto de Botánica del Nordeste (IBONE-CONICET), \\ 3400 Corrientes, Argentina
}

Correspondence should be addressed to Guillermo A. Norrmann, gnorrmann@hotmail.com

Received 1 October 2011; Accepted 25 November 2011

Academic Editor: Jaume Pellicer

Copyright ( $) 2012$ N. Nagahama and G. A. Norrmann. This is an open access article distributed under the Creative Commons Attribution License, which permits unrestricted use, distribution, and reproduction in any medium, provided the original work is properly cited.

\begin{abstract}
Andropogon is a pantropical grass genus comprising 100-120 species and found mainly in the grasslands of Africa and the Americas. In the new world the genus is represented by approximately sixty (diploids or hexaploids) species grouped in three sections. The hexaploid condition occurs only in the Americas and the full process of this origin is still uncertain, although cytogenetic analysis coupled with taxonomic evidence have provided strong support for new hypothesis. Stebbins proposed the first hypothesis suggesting that the origin of polyploidy in species of Andropogon in North America resulted from duplication of the genome of some diploid species, and then by intergeneric crosses with species of a related genus. Since then, numerous studies were performed to clarify the evolutionary history of the genus in America. In this paper, we present a review of cytogenetic studies in the American Andropogon species during the last four decades.
\end{abstract}

\section{Introduction}

Andropogon L. is a pantropical genus of grasses estimated to contain 100 [1] to 120 [2] species, distributed mainly in the grasslands of Africa and the Americas. Andropogon is one of the traditional genera of grasses. Over the course of its circumscription, the genus has included more than 400 species [3] which were subsequently split into several genera [4]. Even considering Andropogon sensu stricto, that is, excluding allied genera such as Bothriochloa Kuntze, Dichanthium Willem., and Schizachyrium Nees, the genus remains somewhat heterogeneous [5], especially in the Americas [6, 7]. In the new world the genus is represented by approximately 60 species (see Table 1 ). The basic chromosome number of the genus is $x=10[6,8-11]$, with only a few exceptions [10]. Most African species are diploids or tetraploids $(2 n=2 x=20 ; 4 x=40)[9,11]$ and American Andropogon species are usually diploid or hexaploid $(2 n=$ $2 x=20$ or $6 x=60)[2,6,7,12,13]$, also with only a few exceptions (see [14]).
Stapf [4] proposed four sections in the genus for African's species: (1) Andropogon Stapf, (2) Leptopogon Stapf, (3) Notosolen Stapf, and (4) Piestium Stapf. Gould [6] suggested the incorporation of American species into the first three taxonomic sections mentioned above; these are currently recognized by Clayton and Renvoize [1]. The Americas are exceptionally rich in Leptopogon Section members, but poor and with hazy boundaries in the other two sections.

Andropogon has diversified into a larger number of species in America and Africa (see Tables 1 and 2) than in Asia or Europe [1, 11]. Genetic differences between American and African (and within) species are poorly understood. Chromosomal evolution, such as polyploidy, appears to be more extensive in America, as hexaploids are almost entirely restricted to this continent (and especially to South America).

In 1985, based on chromosome counts and morphological issues, Norrmann [7] suggested a difference among species from Argentina that could be applied to other South American species. The number of chromosomes allowed 
Table 1: Species of Andropogon distributed in America.

\begin{tabular}{|c|c|c|c|}
\hline Taxa & Distribution & $2 n$ & Section \\
\hline A. aequatoriensis Hitchc. & South America & Probably 60 & Leptopogon \\
\hline A. arctatus Chapm. & Northern America & 20 & $\begin{array}{l}\text { Leptopogon (A. virginicus } \\
\text { complex) }\end{array}$ \\
\hline A. arenarius Hack. & South America & 60 & Leptopogon (A. lateralis complex) \\
\hline A. barretoi Norrmann and Quarin & South America & 60 & Notosolen \\
\hline A. bicornis $\mathrm{L}$. & Americas & 60 & Leptopogon (A. lateralis complex) \\
\hline A. bourgaei Hack. & Northern America & $?$ & Leptopogon \\
\hline A. brachystachyus Chapm. & Northern America & 20 & Leptopogon \\
\hline A. brasiliensis A. Zanin and Longhi-Wagner & South America & $?$ & $?$ \\
\hline A. cabanisii Hack. & Northern America & $?$ & Leptopogon \\
\hline A. campestris Trin. & South America & Probably 60 & Leptopogon \\
\hline A. campii Swalen & South America & $?$ & Leptopogon \\
\hline A. canaliglumis Norrmann, Swenson and Caponio & Central America & Probably 60 & Leptopogon \\
\hline A. carinatus Nees & South America & Probably 20 & Leptopogon \\
\hline A. cordatus Swallen & South America & Probably 60 & Leptopogon \\
\hline A. crassus Sohns & South America & Probably 60 & Notosolen \\
\hline A. crispifolius Guala and Filgueiras & South America & Probably 60 & Notosolen \\
\hline A. cubensis Hack. & Central America & Probably 20 & $?$ \\
\hline A. diuturnus Sohns & South America & Probably 20 & Leptopogon \\
\hline A. durifolius Renvoize & South America & Probably 60 & Notosolen \\
\hline A. elliotii Chapm. & Northern America & 20 & Leptopogon \\
\hline A. ekmanii Norrmann, Swenson and Caponio & Central America & Probably 60 & Leptopogon (A. lateralis complex) \\
\hline A. exaratus Hack. & South America & $60,60+2 B$ & Notosolen \\
\hline A. flavescens J. Presl & South America & Probably 60 & Andropogon \\
\hline A. floridanus Scribn. & Northern America & 20 & $\begin{array}{l}\text { Leptopogon (A. virginicus } \\
\text { complex) }\end{array}$ \\
\hline A. gerardii Vitman & Northern America & $60,70,80,90$ & Andropogon \\
\hline A. glaucescens Kunth & South America & Probably 60 & Andropogon \\
\hline A. glaucophyllus Roseng., B.R. Arrill. and Izag. & South America & 60 & Notosolen \\
\hline A. glaziovii Hack. & South America & 60 & Leptopogon (A.lateralis complex) \\
\hline $\begin{array}{l}\text { A. glomeratus (Walter) Britton, Sterns and } \\
\text { Poggenb. }\end{array}$ & Northern America & 20 & $\begin{array}{l}\text { Leptopogon (A. virginicus } \\
\text { complex) }\end{array}$ \\
\hline $\begin{array}{l}\text { A. glomeratus var. glomeratus (Walter) Britton, } \\
\text { Sterns and Poggenb. }\end{array}$ & Northern America & 20 & $\begin{array}{l}\text { Leptopogon (A. virginicus } \\
\text { complex) }\end{array}$ \\
\hline A. glomeratus var. hirsutior (Hack.) C. Mohr & Northern America & 20 & $\begin{array}{l}\text { Leptopogon (A. virginicus } \\
\text { complex) }\end{array}$ \\
\hline A. glomeratus var. pumilus (Vasey) L. H. Dewey & Northern America & 20 & $\begin{array}{l}\text { Leptopogon (A. virginicus } \\
\text { complex) }\end{array}$ \\
\hline A. gyrans var. gyrans Ashe & Northern America & 20 & $\begin{array}{l}\text { Leptopogon (A. virginicus } \\
\text { complex) }\end{array}$ \\
\hline A. gyrans var. stenophyllus (Hack.) C. S. Campb. & Northern America & 20 & $\begin{array}{l}\text { Leptopogon (A. virginicus } \\
\text { complex) }\end{array}$ \\
\hline A. hallii Hack. & Northern America & $60,70,100$ & Andropogon \\
\hline A. herzogii Hack. & South America & Probably 60 & Leptopogon \\
\hline A. hondurensis (R.W. Pohl) Wipff & Central America & 80 & Andropogon \\
\hline A. hypogynus Hack. & $\begin{array}{l}\text { South and Central } \\
\text { America }\end{array}$ & 60 & Leptopogon (A. lateralis complex) \\
\hline
\end{tabular}


TABle 1: Continued.

\begin{tabular}{|c|c|c|c|}
\hline Taxa & Distribution & $2 n$ & Section \\
\hline A. indetonsus Sohns & South America & Probably 60 & Leptopogon \\
\hline A. lateralis Nees & $\begin{array}{l}\text { South and Central } \\
\text { America }\end{array}$ & $60,60+2 B$ & Leptopogon (A. lateralis complex) \\
\hline A. leucostachyus Kunth & $\begin{array}{l}\text { South and Central } \\
\text { America }\end{array}$ & 20 & Leptopogon \\
\hline A. liebmannii Hack. & Northern America & 20 & Leptopogon \\
\hline $\begin{array}{l}\text { A. liebmannii Hack. var. pungensis (Ashe) } \\
\text { C. S. Campb. }\end{array}$ & Northern America & 20 & Leptopogon \\
\hline A. lindmanii Hack. & South America & 60 & Leptopogon (A. lateralis complex) \\
\hline A. longiberbis Hack. & Northern America & 20 & $\begin{array}{l}\text { Leptopogon (A. virginicus } \\
\text { complex) }\end{array}$ \\
\hline A. longiramosus Sohns & South America & $?$ & Leptopogon \\
\hline A. macrothrix Trin. & South America & 20 & Leptopogon \\
\hline A. monocladus A. Zanin and Longhi-Wagner & South America & $?$ & $?$ \\
\hline A. nashianus Hitchc. & Central America & Probably 20 & Leptopogon \\
\hline A. palustris Pilg. & South America & Probably 20 & $?$ \\
\hline A. perdignus Sohns & South America & Probably 60 & Andropogon \\
\hline A. pohlianus Hack. & South America & Probably 60 & Notosolen \\
\hline A. pringlei Scribn. and Merr. & Northern America & $?$ & probably Leptopogon \\
\hline A. reedii Hitchc. and Ekman & Central America & Probably 20 & Leptopogon \\
\hline A. reinoldii León & Central America & Probably 20 & Leptopogon \\
\hline A. sanlorenzousa Killeen & South America & Probably 20 & Leptopogon \\
\hline A. scabriglumis Swallen & South America & Probably 60 & Leptopogon \\
\hline A. selloanus (Hack.) Hack. & $\begin{array}{l}\text { South and Central } \\
\text { America }\end{array}$ & 20 & Leptopogon \\
\hline A. sincoranus Renvoize & South America & $?$ & Leptopogon \\
\hline A. spadiceus Swallen & Northern America & $?$ & $?$ \\
\hline A. ternarius Michx. & Northern America & 40,60 & Leptopogon \\
\hline $\begin{array}{l}\text { A. ternarius var cabanisii (Hack) Fernald } \\
\text { and Griscom }\end{array}$ & Northern America & $?$ & Leptopogon \\
\hline A. ternatus (Spreng.) Nees & South America & 30 & Leptopogon \\
\hline A. tracyi Nash & Northern America & 20 & $\begin{array}{l}\text { Leptopogon (A. virginicus } \\
\text { complex) }\end{array}$ \\
\hline A. urbanianus Hitchc. & Central America & 80 & Leptopogon \\
\hline A. virginicus $\mathrm{L}$. & Northern America & 20 & $\begin{array}{l}\text { Leptopogon (A. virginicus } \\
\text { complex) }\end{array}$ \\
\hline A. virginicus var. glaucus Hack. & Northern America & 20 & $\begin{array}{l}\text { Leptopogon (A. virginicus } \\
\text { complex) }\end{array}$ \\
\hline A. virginicus var. virginicus L. & Northern America & 20 & $\begin{array}{l}\text { Leptopogon (A. virginicus } \\
\text { complex) }\end{array}$ \\
\hline A. vetus Sohns & South America & Probably 60 & $?$ \\
\hline
\end{tabular}

discriminating the genus Andropogon into two main groups: a few species are diploid $(2 n=2 x=20)$, small in size with colonizing habit; other ten species are hexaploid $(2 n=6 x=$ $60)$, larger in size and with varied habitat. South American species consistently display one ploidy level, with hexaploids being considered of alloploid origin [7]. In contrast, there are a few exceptions in North America. For example, two species show intraspecific variation: Andropogon ternarius with $2 n=40$ and 60 (which needs reconfirmation) and Andropogon gerardii with $2 n=60$ and 90 .
To resolve genomic relationships between Andropogon species in the new world, many studies were performed until the present. In this paper we present a review of the published results and a general discussion of them.

\section{Andropogon Section}

In the Americas the Andropogon section is well represented by two species $A$. gerardii Vitman and A. hallii Hack., distributed mainly in the Northern Hemisphere [14]. The 
two species are predominantly hexaploid $(2 n=60)$ plants [15-20], however there are populations with high frequency of enneaploids $(2 n=90)[19,21-23]$. Both species cross in habitat hybridizing zones (e.g., Nebraska sand hills) and hybrid swarms are formed (see [14, 24]). Hybridization in the $A$. gerardii-A. hallii complex was recorded as early as 1891, when an individual was collected in Kansas and described as A. chrysocomus Nash [24]. Although hybrids in this combination are fertile, they disappear outside the hybridization habitat, indicating that the species are ecologically distinct [14]. Other members of the section worth mentioning are A. glaucescens in South America (no chromosomes count) and $A$. hondurensis (R.W. Pohl) Wipff, with chromosome counts of $2 n=80$.

Stebbins [8] suggested that the polyploid origin of $A$. gerardii in North America could be caused by polyploidization of some diploid of the "Cotton Belt" region, resulting in the constitution of the tetraploid A. ternarius (included into the Leptopogon section), and then by intergeneric crosses of this tetraploid with species of Bothriochloa, which at that time were still regarded as members of Andropogon, sect. Amphilopis. Bothriochloa includes several species that are adapted to the more arid portions of western North America, and therefore such an origin would be compatible with the more xeric nature of $A$. gerardii. Since at the present time no diploid or tetraploid Bothriochloa species exists in North America, Stebbins [8] assumed that the ancestor of these higher polyploids is now extinct.

Norrmann et al. [19] described the meiotic and reproductive behavior in $6 x$ and $9 x$ cytotypes of $A$. gerardii, and the viability of their hybrids. The meiosis in $A$. gerardii was regular in the hexaploids but irregular in the enneaploids. The hexaploid cytotypes $(2 n=6 x=60)$ are fully fertile and produce gametes that uniformly contain 30 chromosomes. Minimal embryo sac abortion and good seed production follow. In the enneaploids, "heptaploids," "octoploids," and aneuploids with $2 n=68-78$, gametes frequently abort.

Under controlled pollination, the two common cytotypes can be crossed, producing progeny with a range of chromosome numbers with less fertility [25].

In some natural populations of $A$. gerardii high frequencies of hexaploids and enneaploids, also plants with an intermediate chromosome numbers occur [19, 21, 23]. Populations dominated by or composed of only enneaploids would be much less fertile than mixed populations [19], and indeed such populations are rare to nonexistent [23]. Norrmann and Keeler [25] suggested that the predominance of the hexaploids is related to the higher level of fitness and this could eliminate other cytotypes. In addition the authors suggest that the enneaploids are produced from a hexaploid's unreduced gamete combining with a reduced gamete $(2 n=$ $60+30=90)$.

\section{Notosolen Section}

Only three South American $(2 n=6 x=60)$ species [13] included in this section have yielded chromosome counts: A. barretoi Norrmann and Quarin, A. exaratus Hack. and
A. glaucophyllus Roseng., B. R. Arrill. and Izag. The section was considered the most primitive in South America, because of its closeness with species from West Africa $[1,26]$.

The geographic distribution of these species is relatively restricted and they are not sympatric anymore, even though they live no more than $1000 \mathrm{mi}$. from each other. However, the hybrid combinations in artificial crossings between the more geographically distant species (A. exaratus $\times A$. glaucophyllus) are possible and they are fully fertile [11]. Because of the fertility of interspecific hybrids, Norrmann [11] proposed that they have a highly related genomic composition and a probably common origin. The hybrid combinations between $A$. barretoi, A. exaratus, A. glaucophyllus and the trihybrid (A. exaratus $\times$ A. glaucophyllus $) \times$ A. barretoi are under analysis.

\section{Leptopogon Section}

Leptopogon is considered the most advanced section within the genus $[1,2,11]$ and is characterized by the presence of a concave nerveless first glume of the sessile spikelet [26]. In the Americas, the section is mainly represented by two complexes: A. virginicus L., distributed in North America [9] and the A. lateralis Ness complex covering South and Central America.

Documented American diploids of this section are represented by twelve species. Nine of them belong to the $A$. virginicus complex (Table 1 ), and the other three species are distributed in South and Central America: $A$. leucostachyus Kunth, A. macrothrix Trin., and A. selloanus (Hack.) Hack. Another South American species, A. ternatus (Spreng.) Nees. maintains permanent triploidy $(2 n=3 x=$ 30) by transmitting one genome through the egg cell and two genomes through the sperm nucleus [27]. This species may be best regarded as a diploid with an additional accessory chromosomes set $[7,27]$.

The hexaploid species are all included in the A. lateralis complex and are represented by 10 species restricted to South and Central America, except for A. bicornis which has the widest geographical distribution in the group and is also present in North America.

Other uncommon ploidy levels are represented in $A$. Notosolen Michx. $(2 n=40)$ and A. urbanianus Hitchc. $(2 n=80)$.

4.1. Andropogon Virginicus Complex. In North America the A. virginicus complex is a closely interrelated group of nine diploid species $[9,28]$. These species frequently grow together but rarely produce apparent hybrids [9]. They are effectively reproductively isolated from one another without being separated by large morphological gaps.

Norrmann et al. [29] by genomic in situ hybridization (GISH) studies observed that the South American diploids A. selloanus and A. macrothrix, and the North American diploid A. gyrans Ashe (A. virginicus complex member), share the basic $S$ genome (Figures $1(\mathrm{a})-1(\mathrm{~d})$ ). This was previously proposed based on classical hybridization and meiotic chromosome behavior studies by Galdeano and Norrmann [12] for the first two species and reveals that the S 
Table 2: Species of Andropogon distributed in Africa.

\begin{tabular}{|c|c|c|c|}
\hline Taxa & Distribution & $2 n$ & Section \\
\hline A. abyssinicus R. Br. ex Fresen. & East Africa & 32 & Andropogon \\
\hline A. africanus Franch. & Africa & 40 & Leptopogon \\
\hline A. amethystinus Steud. & Africa & 20, c. 30 & Andropogon \\
\hline A. amplectens Nees & Southern Africa & 40 & Piestium \\
\hline A. appendiculatus Nees & Southern Africa & $20,40,60$ & Notosolen \\
\hline A. ascinodis C.B. Clarke & Africa and India & 40 & probably Notosolen \\
\hline A. auriculatus Stapf & West Africa & $?$ & $?$ \\
\hline A. brachyatherus Hochst. & Southern Africa & 20 & $?$ \\
\hline A. brazzae Franch. & Southern Africa & 20,40 & $?$ \\
\hline A. canaliculatus Schumach. & Africa & 20 & Piestium \\
\hline A. chevalieri Reznik & West Africa & $?$ & $?$ \\
\hline A. chinensis (Nees) Merrill & Africa and Asia & $?$ & Piestium \\
\hline A. chrysostachyus Steud. & East Africa & $?$ & $?$ \\
\hline A. curvifolius Clayton & West Africa & 20 & Leptopogon \\
\hline A. distachyos L. & Africa/Europe & 36,40 & Andropogon \\
\hline A. dummeri Stapf & West Africa & 20 & $?$ \\
\hline A. eucomus Nees & Africa & 20,40 & $?$ \\
\hline A. filifolius (Nees) Steud & Southern Africa & $?$ & Piestium \\
\hline A. gabonensis Stapf & West Africa & 20,21 & $?$ \\
\hline A. gayanus Kunth & Africa and Asia & $\begin{array}{c}20,35,40,42,43 \\
44\end{array}$ & Notosolen \\
\hline $\begin{array}{l}\text { A. gayanus Kunth var bisquamulatus } \\
\text { (Hochst.) Hack. }\end{array}$ & Africa and Asia & 40 & Notosolen \\
\hline A. gayanus Kunth var gayanus & Africa and Asia & 40 & Notosolen \\
\hline $\begin{array}{l}\text { A. gayanus Kunth var squamulatus (Hochst) } \\
\text { Stapf. }\end{array}$ & Africa and Asia & 40 & Notosolen \\
\hline A. guianensis Kunth ex Steud. & Africa & 40 & $?$ \\
\hline A. heterantherus Stapf & East Africa & $?$ & Piestium \\
\hline A. huillensis Rendle & Southern Africa & $20,60,100$ & Leptopogon \\
\hline A. ivorensis Adjan. and Clayton & West Africa & 40 & $?$ \\
\hline A. kilimandscharicus Pilger & Africa & 20 & Andropogon \\
\hline A. laxatus Stapf & Africa & $?$ & Leptopogon \\
\hline A. lima (Hack.) Stapf & Africa & $?$ & Andropogon \\
\hline A. macrophyllus Stapf & West Africa & 40 & $?$ \\
\hline A. mannii Hook. f. & Africa & 14 & Andropogon \\
\hline A. patris Robyns & Africa & 20 & $?$ \\
\hline A. perligulatus Stapf & Africa & 20 & $?$ \\
\hline A. pinguipes Stapf & West Africa & $?$ & $?$ \\
\hline A. pratensis Hochst. & West Africa & $?$ & Andropogon \\
\hline A. pseudapricus Stapf & Africa & 20,40 & Piestium \\
\hline A. pusillus Hook. f. & West Africa & $?$ & $?$ \\
\hline A. schinzii Hack. & Africa & 20,40 & Piestium \\
\hline A. schirensis Hochst. ex A. Rich. & Africa & 20,40 & Piestium \\
\hline A. tectorum Schumach. and Thonn. & West Africa & $20,23,30,40$ & Notosolen \\
\hline A. textilis Rendle & East Africa & $?$ & Piestium \\
\hline
\end{tabular}




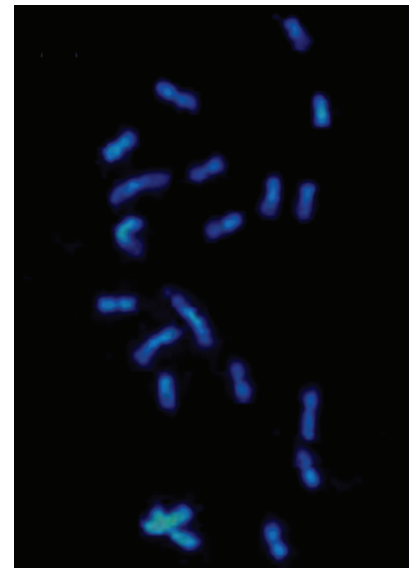

(a)

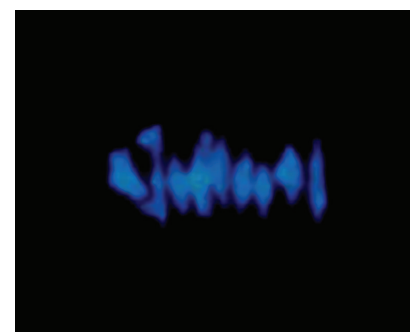

(c)

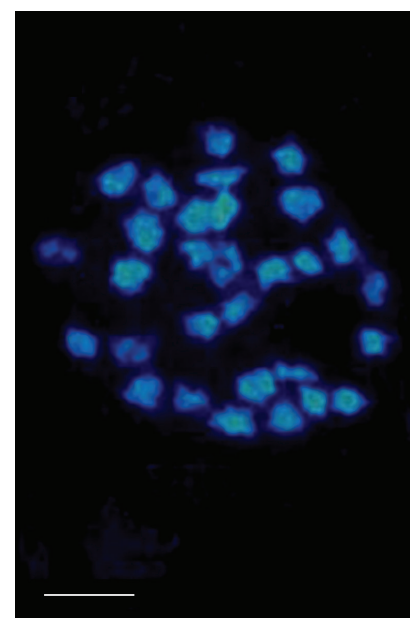

(g)

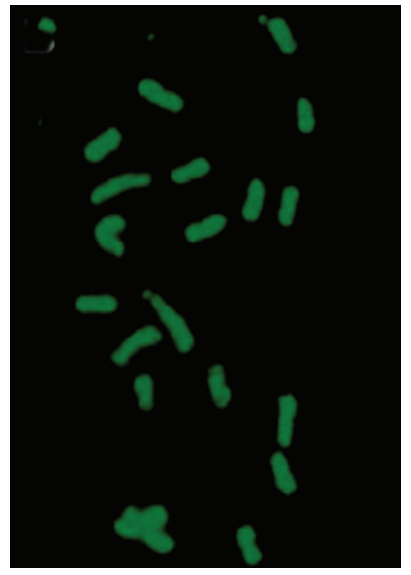

(b)

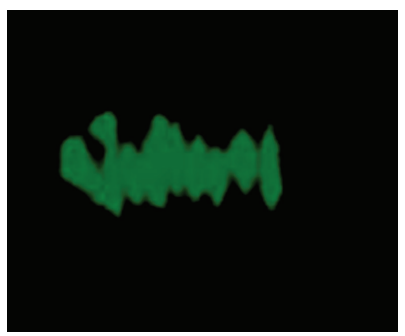

(d)

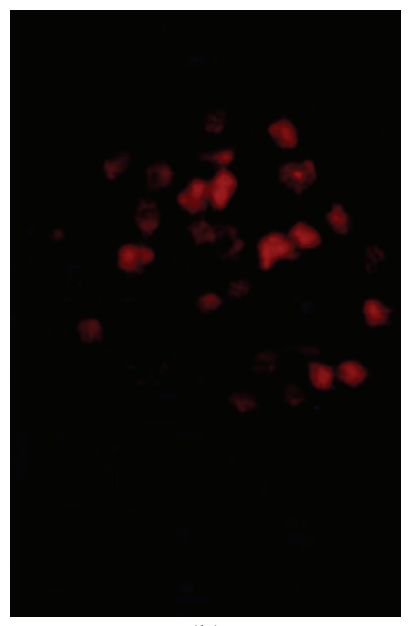

(h)

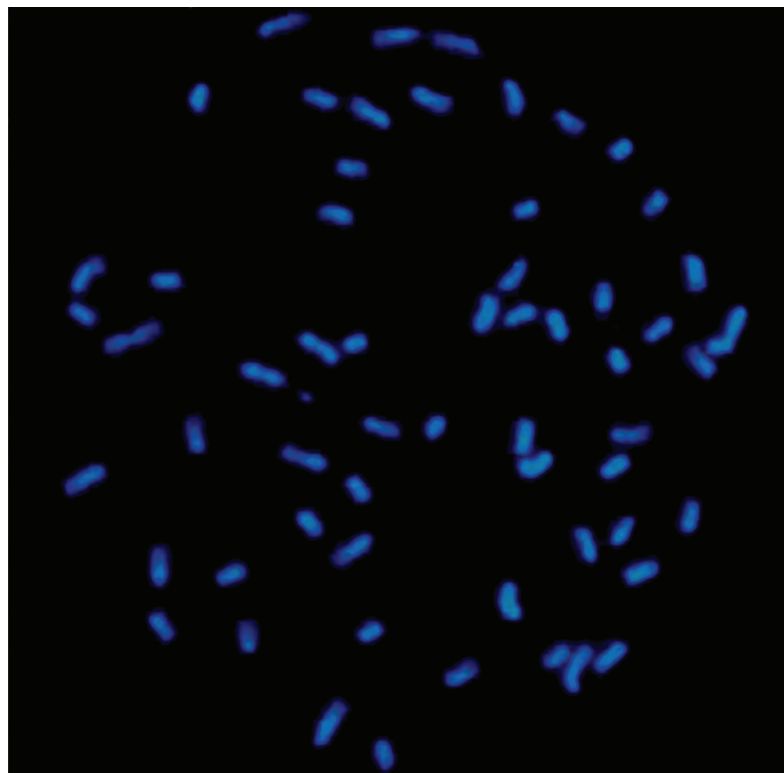

(e)

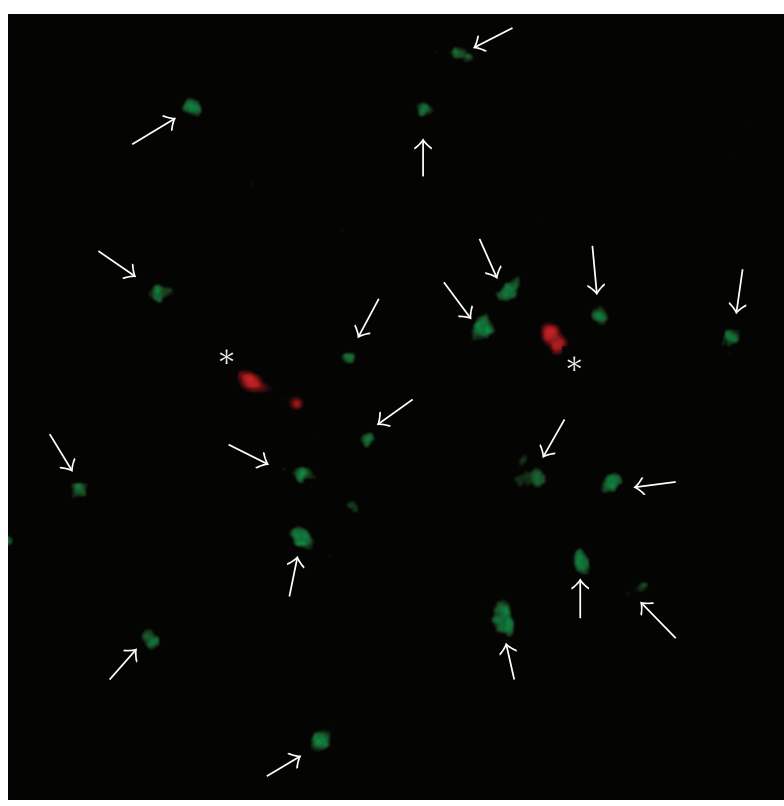

(f)

FIGURE 1: GISH on mitotic and meiotic metaphase chromosomes of (a-d) diploid $(2 n=2 x=20)$ and $(\mathrm{e}-\mathrm{h})$ hexaploid $(2 n=6 x=60)$ Andropogon species. (a) and (b) Mitotic chromosomes of SA diploid A. selloanus probed with genomic DNA from SA diploid A. macrothrix and detected with green fluorescence. (a) DAPI-stained chromosomes; (b) GISH showing all 20 chromosomes fluorescing green. (c) and (d) Meiotic chromosomes of SA diploid A. selloanus probed with genomic DNA from the NA diploid A. gyrans and detected with green fluorescence. (c) DAPI-stained chromosomes; (d) GISH showing all 10 bivalents fluorescing green. (e) and (f) Mitotic chromosomes of SA hexaploid A. lateralis probed simultaneously with genomic DNA from the SA diploid A. selloanus (green fluorescence) and pTa71 (red fluorescence). (e) DAPI-stained chromosomes; (f) GISH showing 20 chromosomes fluorescing green ( $S$ genome chromosomes, arrows) and two sites of red hybridization (asterisks) corresponding to the location of the 18S.25S rDNA on two chromosomes that do not fluoresce green and thus do not originate from the S genome. $(\mathrm{g})$ and $(\mathrm{h})$ Meiotic chromosomes of SA hexaploid A. lateralis probed with genomic DNA from the NA diploid A. gyrans and detected with red fluorescence. (g) DAPI-stained chromosomes; (h) GISH showing approximately 10 bivalents fluorescing red. Scale bar $=2 \mu \mathrm{m}$. Figure extracted from [29]. 
genome, originally defined for the South American diploids, is also shared by the North American diploid A. gyrans. Since A. gyrans is a member of the Andropogon virginicus group, whose monophyly was demonstrated by classical taxonomy [9], it is likely that the remaining members of the A. virginicus group also contain the $S$ genome [29].

4.2. Andropogon lateralis Complex. This section is geographically distributed in South and Central America and is constituted entirely by hexaploid species: A. arenarius Hack., A. bicornis L., A. glaziovii Hack., A. hypogynus Hack., A. lateralis Nees, $A . \times$ subtilior (Hack.) Norrmann (pro. spp.), A. $\times$ lindmanii Hack. (pro. spp.), and $A . \times$ coloratus Hack. (pro. spp.), among others, which present the anther size and the number of pollen grains in fertile sessile spikelets strongly reduced compared with those of pedicellate spikelets. This synapomorphy of dimorphic anthers defines this complex $[2,9]$. Within this complex, natural interspecific hybrids have been reported, where populations of different species live in sympatry. Three combinations were reported by Campbell and Windish [2] and two more by Norrmann [11]. Of the ten taxa that comprise the complex in the southern area of South America, five are legitimate species and the others are interspecific hybrids [30].

Norrmann et al. [29] performed GISH studies on two hexaploid species of the A. lateralis complex: A. lateralis and A. bicornis. Hybridization of genomic DNA from the South American diploid A. selloanus onto mitotic chromosomes of the South American hexaploid A. lateralis resulted in only 20 out of the 60 chromosomes showing strong green fluorescence (Figures 1(e) and 1(f)). These results indicate that $A$. lateralis is an allohexaploid in which the $S$ genome comprises only one of the other genomes. Interestingly, however, the 20 $S$ genome chromosomes were not uniformly labeled along their entire length (as in the diploids, see Figures 1(a)$1(d)$ ); instead, the labeling was mainly concentrated in the pericentromeric regions. These results suggest that there has been some divergence of the repetitive sequences in the distal regions of the $\mathrm{S}$ genome chromosomes since the allopolyploid was formed so that they no longer hybridize to the $\mathrm{S}$ genome probe.

When meiotic chromosomes of $A$. lateralis were probed with genomic DNA from the North American diploid $A$. gyrans, the overall results were similar to those using the South American diploid A. selloanus as a probe, although slight differences in labeling intensity were sometimes observed, suggesting once again that there has been some divergence of the repetitive DNA sequences between the $\mathrm{S}$ genome in the North American diploid and hexaploid species as suggested above for $A$. lateralis (Figures $1(\mathrm{~g})-1(\mathrm{~h})$ ).

Norrmann [30] analyzed the chromosomes and meiotic behavior between interspecific hybrids into the $A$. lateralis complex and observed that all studied hybrids showed $2 n=$ 60 chromosomes which pair to form up to 30 bivalents per pollen mother cell. The high frequency of bivalents observed in all crosses ( 30 observed, of 30 maximum) points to the existence of ancient chromosomal homology or homoeology in all species treated, with small differences among the "three" basic genomes (see [29]).

\section{Intersectional Analysis}

Norrmann [11] crossed A. barretoi (Notosolen) with A. gerardii (section Andropogon) and observed a high chromosome pairing in these hybrids. But this pairing does not result from true homology, according to genomic in situ (GISH) experiments carried out recently (Norrmann and Leitch, unpubl. data), which evidence very low homologies among chromosomes from each parental species. The formation of multivalent as a divergence phenomenon is strongly suggested by the odd meiosis, with irregular segregation and formation of multiple nuclei.

Intersectional hybrids among A. lateralis (Leptopogon) and $A$. exaratus (Notosolen) occur in nature and can be experimentally produced [11]. GISH experiments carried on this hybrid revealed very low homologies among these species (Norrmann and Leitch, in prep). On the other hand, upon direct labeling of A. gerardii (Andropogon) onto A. bicornis (Leptopogon), much more homologies appear (Norrmann and Leitch, in prep). All these results suggest section Notosolen has no close relationships to Andropogon or to Leptopogon sections.

Finally, preliminary results on A. gerardii chromosomes hybridizing to probes from $A$. gyrans suggest a genomic formula SS $S^{1} S^{1} \mathrm{XX}$ for $A$. gerardii with one genome close to A. gyrans $(\mathrm{S})$, another less related $\left(\mathrm{S}^{1}\right)$, and a third unrelated (X) (Nagahama and Norrmann, unpubl. data).

\section{Discussion}

To resolve genomic relationships between Andropogon species, previous studies have successfully made interspecific hybrids among diploids [12], among diploids and triploids [27], among hexaploids [11, 19, 30,31], between hexaploids with enneaploids and inner aneuploids $[19,25]$ and among diploid and hexaploid species [29]. While the later study suggests that the diploid South American species A. selloanus and A. macrothrix and the North American diploid A. gyrans share a common genome, relationships between the North and South American species are still unclear. This was due in part to the failure to make diploid $\times$ hexaploid crosses in several combinations [12].

Stebbins [8] suggested that the North American hexaploids (A. gerardii) probably were originated in the new world through processes of polyploidization of diploid species of Andropogon, followed by hybridization with species of Bothriochloa. Several events have happened since then. First, this hypothesis was proposed by the time hexaploids in South America were not known, as the first chromosome counts were published between 1985 [7] and 1986 [2]. Second, GISH experiences suggest that Bothriochloa and Andropogon have stronger chromosomal divergences than thought before (Norrmann, unpubl. data). Finally, the similarity suggested by Stebbins [8] among species of the genera Andropogon and Bothriochloa actually are recognized as evolutionary convergence [1]. Moreover, Stebbins' hypothesis suggests that $A$. gerardii and other polyploid complexes were distributed on the plains of central North America about 5 million years ago. However, due to 
the last glaciations, it is known that the colonization of the North American prairies by this species was recent, and this happened not earlier than 10,000 years ago. Nowdays, there is consensus in the origin of A. gerardii in Central America or Northern South America, and after the retreat of the ice, it would have colonized the North American plains. This hypothesis is also supported by the octoploid A. hondurensis, distributed in Central America, due to that this species is related with $A$. gerardii, being considered in the past as subspecies of $A$. gerardii (see [32]).

Stebbins' hypothesis has two parts: first, the conformation of a tetraploid from diploids of the cotton belt and second, the hybridization with Bothriochloa species. As we have explained before, second part needs modification but part 1, that is, the generation of hexaploids as an American evolutionary process stands still as the more solid hypothesis, at least for A. gerardii and the A. lateralis complex, and would also have occurred in genera related to Andropogon, for example in Bothriochloa [8,33,34]. This hypothesis is sustained by GISH experiments pointing to the $S$ genome as being part of $A$. gerardii and the A. lateralis genome. Different forms of the $S$ genome are present in American diploid species, as A. selloanus or the A. virginicus complex and none of these species lives in Africa. Therefore, the origin of $A$. gerardii and the A. lateralis complexes could be American, with the providers of the other/s genomes still not found.

On the other hand, it is worth mentioning other hypothesis for the origin of the hexaploids. Norrmann [11] suggested that one or more ancestral hexaploids might have been established both in America and Africa at least in the Cretaceous (60 million years ago). The lack of hexaploid species in Africa could be due to these polyploids proliferating adaptively in America, and not in Africa due to selective pressure, because the continent underwent dramatic changes and rigorous conditions after the separation from the Americas [35, 36]. Another possibility is that the hexaploids do exist, but they have not been found. There are records of an African hexaploid (A. huillensis Rendle) [37], but in this species also are recorded chromosome counts with $2 n=20$ [38] and $2 n=100$ [39], suggesting that this polyploidization was because of genome duplication (autopolyploid), and not as in the American hexaploids which are allopolyploids.

Our view of the Andropogons in America is much complete nowadays than it was in 1975. Great advances have been made in major issues, as the understanding of the A. virginicus, the A. lateralis, and the A. gerardii-A.hallii complexes and their cytogenetics.

GISH technique has proved useful and overcomes the difficulty in making $2 x-6 x$ hybrids and studying intersectional hybrids. Also, preliminary results based on molecular marker analysis suggest that in the A. lateralis complex there are at least two clearly different genomes. On the other hand, the three genomes of sect. Notosolen appear to be related (Nagahama and Norrmann, unpubl. data).

We need to be cautious about the comprehension of the whole genus since we are still based on chromosome counts made for only a portion of the species. No cytogenetic information is available from northern Brazilian species, or from Venezuela, Colombia, Equator, Peru (A. glaucescens and A. flavescens from the Andropogon section) and other species from Central America and West Indies. If diploids could be differentiated from hexaploids by its size, as Norrmann proposed [7], then many South and Central American species could be candidates to look for other genome sources different from S (see Table 1).

Finally, old grasslands hexaploid species as A. gerardii and members of the $A$. lateralis complex are under the anthropogenic pressure. The days of the North American plains covered with A. gerardii feeding bison, or Venezuelan "llanos" and "campos" of southern South America (NE Argentina, S Brazil, Paraguay, Uruguay) dominated by $A$. lateralis and A. hypogynus are not the actual picture, but the species are still there. Concern should perhaps be put on the few American members of the Notosolen section: $A$. exaratus survives well because it lives on the marshes, but $A$. glaucophyllus (in dunes of southern Brazil and Uruguay) is loosing presence. The worse situation we are aware is that of A. barretoi, which can only be found alongside the road Santa María to Porto Alegre, as related to one of us by Professor Ismar Barreto, the real discoverer of the species back in 1982. Today, the habitat stretches no more than $10 \mathrm{mi}$. along the roadside.

\section{References}

[1] W. D. Clayton and S. A. Renvoize, Genera Graminum. Grasses of the World, Kew Bulletin Additional Series 13, 1986.

[2] C. S. Campbell and P. G. Windisch, "Chromosome numbers and their taxonomic implications for eight Brazilian Andropogons (Poaceae: Andropogoneae)," Brittonia, vol. 38, no. 4, pp. 411-414, 1986.

[3] E. G. Steudel, Synopsis Plantarum Glumacearum, vol. 1 of Synopsis Plantarum Graminearum, J.B. Metzler, Stuttgart, Germany, 1855.

[4] O. Stapf, "Gramineae," in Flora of Tropical Africa, D. Prain, Ed., vol. 9, pp. 208-265, Reeve, London, UK, 1919.

[5] W. D. Clayton, “Andropogon pteropholis," Hooker's Icones Plantarum, vol. 37: t. 3644, 1967.

[6] F. W. Gould, "The grass genus Andropogon in the United States," Brittonia, vol. 19, no. 1, pp. 70-76, 1967.

[7] G. A. Norrmann, "Estudios citogenéticos en especies argentinas de Andropogon (Gramineae)," Boletin de la Sociedad Argentina de Botanica, vol. 24, pp. 137-149, 1985.

[8] L. G. Stebbins, "The role of polyploid complexes in the evolution of North American grasslands," Taxon, vol. 24, pp. 91-106, 1975.

[9] C. S. Campbell, "Systematics of the Andropogon virginicus complex (Gramineae)," Journal of Arnold Arboretum of Harvard University, vol. 64, pp. 171-254, 1983.

[10] G. Davidse, T. Hoshino, and B. K. Simon, "Chromosome counts of Zimbabwean grasses (Poaceae) and an analysis of polyploidy in the grass flora of Zimbabwe," South African Journal of Botany, vol. 52, pp. 521-528, 1986.

[11] G. A. Norrmann, Biosistemática y relaciones filogenéticas en especies hexaploides sudamericanas de Andropogon (Gramineae), Ph.D. thesis, Facultad de Ciencias Exactas Físicas y Naturales, Universidad Nacional de Córdoba, 1999.

[12] F. Galdeano and G. Norrmann, "Natural hybridization between two South American diploid species of Andropogon 
(Gramineae)," Journal of the Torrey Botanical Society, vol. 127, no. 2, pp. 101-106, 2000.

[13] G. A. Norrmann and F. Scarel, "Biología reproductiva de cuatro especies sudamericanas hexaploides de Andropogon L. (Gramineae, Andropogoneae)," Kurtziana, vol. 28, pp. 173$180,2000$.

[14] A. Boe, K. Keeler, G. A. Norrmann, and S. Hatch, "The indigenous bluestems (Bothriochloa, Andropogon and Schizachyrium) of the western Hemisphere and gamba grass (Andropogon gayanus)," in Warm Season Grasses, L. Moser, B. Byron, and L. Sollenberger, Eds., Agronomy Series: 45, pp. 873-908, Madison, Wis, USA, American Society of Agronomy, Crop Science Society of America, Soil Science Society of America, 2004.

[15] E. L. Nielsen, "Grass studies. III. Additional somatic chromosome compliments," American Journal of Botany, vol. 26, pp. 366-372, 1939.

[16] F. W. Gould, "Cromosome counts and cytotaxonomic notes on grasses of the tribe Andropogoneae," American Journal of Botany, vol. 43, pp. 395-404, 1956.

[17] G. W. Dewald and S. M. Jalal, "Meiotic behavior and fertility interrelationship in Andropogon scoparius and A. gerardii," Cytologia, vol. 39, pp. 215-223, 1974.

[18] R. D. Riley and K. P. Vogel, "Chromosome numbers of released cultivars of switchgrass, Indian-grass, big bluestem, and sand bluestem," Crop Science, vol. 22, pp. 1081-1083, 1982.

[19] G. A. Norrmann, C. L. Quarín, and K. H. Keeler, "Evolutionary implications of meiotic chromosome behavior, reproductive biology, and hybridization in 6x and 9x cytotypes of Andropogon gerardii (Poaceae)," American Journal of Botany, vol. 84, no. 2, pp. 201-207, 1997.

[20] K. P. Vogel, "Improving warm-season forage grasses using selection, breading, and biotechnology," in Native WarmSeason Grasses: Research Trends and Issues, K. J. Moore and B. E. Anderson, Eds., pp. 83-106, Crop Science Society of America Special Publication 30, American Society of Agronomy, Madison, Wis, USA, 2000.

[21] K. H. Keeler and G. A. Davis, "Comparison of common cytotypes of Andropogon gerardii (Andropogoneae, Poaceae)," American Journal of Botany, vol. 86, no. 7, pp. 974-979, 1999.

[22] K. H. Keeler, "Distribution of polyploid variation in big bluestem (Andropogon gerardii, Poaccea) across the tallgrass prairie region," Genome, vol. 33, no. 1, pp. 95-100, 1990.

[23] K. H. Keeler, "Local polyploid variation in the native prairie grass A. gerardii," American Journal of Botany, vol. 79, pp. 1229-1232, 1992.

[24] J. K. Wipff, "Nomenclatural combinations in the Andropogon gerardii complex (Poaceae: Andropogoneae)," Phytologia, vol. 80, pp. 343-347, 1996.

[25] G. A. Norrmann and K. H. Keeler, "Cytotypes of Andropogon gerardii Vitman (Poaceae): fertility and reproduction of aneuploids," Botanical Journal of the Linnean Society, vol. 141, no. 1, pp. 95-103, 2003.

[26] W. D. Clayton, "Gramineae," in Flora of West Tropical Africa, F. N. Hepper, Ed., vol. 3, part 2, pp. 349-512, Crown Agents for Overseas Governments and Administrations, London, UK, 2nd edition, 1972.

[27] G. A. Norrmann and C. L. Quarin, "Permanent odd polyploidy in a grass (Andropogon ternatus)," Genome, vol. 29, pp. 340-344, 1987.

[28] C. S. Campbell, "Hybridization between Andropogon glomeratus var. pumilus and A. longiberbis (Gramineae) in Central Florida," Brittonia, vol. 34, pp. 146-150, 1982.
[29] G. Norrmann, L. Hanson, S. Renvoize, and I. J. Leitch, "Genomic relationships among diploid and hexaploid species of Andropogon (Poaceae)," Genome, vol. 47, no. 6, pp. 12201224, 2004.

[30] G. A. Norrmann, "Natural hybridization in the Andropogon lateralis complex (Andropogoneae, Poaceae) and its impact on taxonomic literature," Botanical Journal of the Linnean Society, vol. 159, no. 1, pp. 136-154, 2009.

[31] L. C. Peters and L. V. Newell, "Hybridization between divergent types of big bluestem, Andropogon gerardii Vitman, and sand bluestem, Andropogon hallii E. Hackel," Crop Science, vol. 1, pp. 359-363, 1961.

[32] G. Davidse and R. W. Pohl, "Chromosome numbers, meiotic behavior, and notes on some grasses from Central America and The West Indies," Canadian Journal of Botany, vol. 50, pp. 1441-1452, 1972.

[33] F. W. Gould., "A citotaxonomic study in the genus Andropogon," American Journal of Botany, vol. 40, pp. 297-306, 1953.

[34] L. R. Scrivanti, I. Caponio, A. M. Anton, and G. A. Norrmann, "Chromosome number in South American species of Bothriochloa (Poaceae: Andropogoneae) and evolutionary history of the genus," Plant Biology, vol. 12, no. 6, pp. 910-916, 2010.

[35] P. W. Hattersley and L. Watson, "Diversification of photosynthesis," in Grass Evolution and Domestication, G. P. Chapman, Ed., pp. 38-116, Cambridge University Press, Cambridge, UK, 1992.

[36] P. H. Raven and D. Axelrod, "Angiosperm biogeography and past continental movements," Annals of the Missouri Botanical Garden, vol. 61, pp. 539-673, 1974.

[37] J. M. J. De Wet, "Chromosome numbers and some morphological attributes of various South African grasses," American Journal of Botany, vol. 47, pp. 44-49, 1960.

[38] M. Dujardin, "Chromosome numbers of some tropical African grasses from western Zaire," Canadian Journal of Botany, vol. 57, pp. 864-876, 1978.

[39] J. J. Spies and H. Du Plessis, "Chromosome studies on African plants. 3,” Bothalia, vol. 17, pp. 257-259, 1987. 

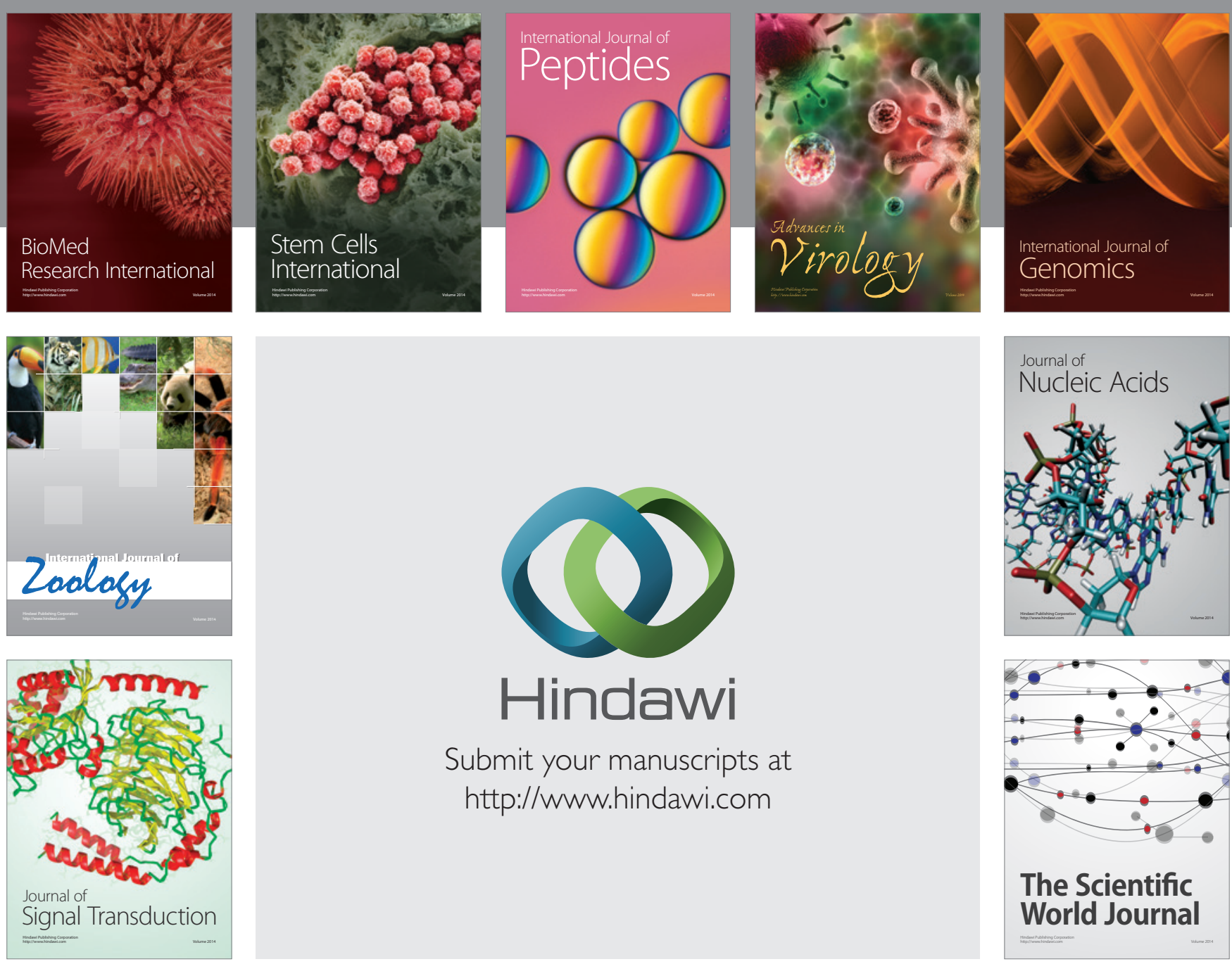

Submit your manuscripts at

http://www.hindawi.com
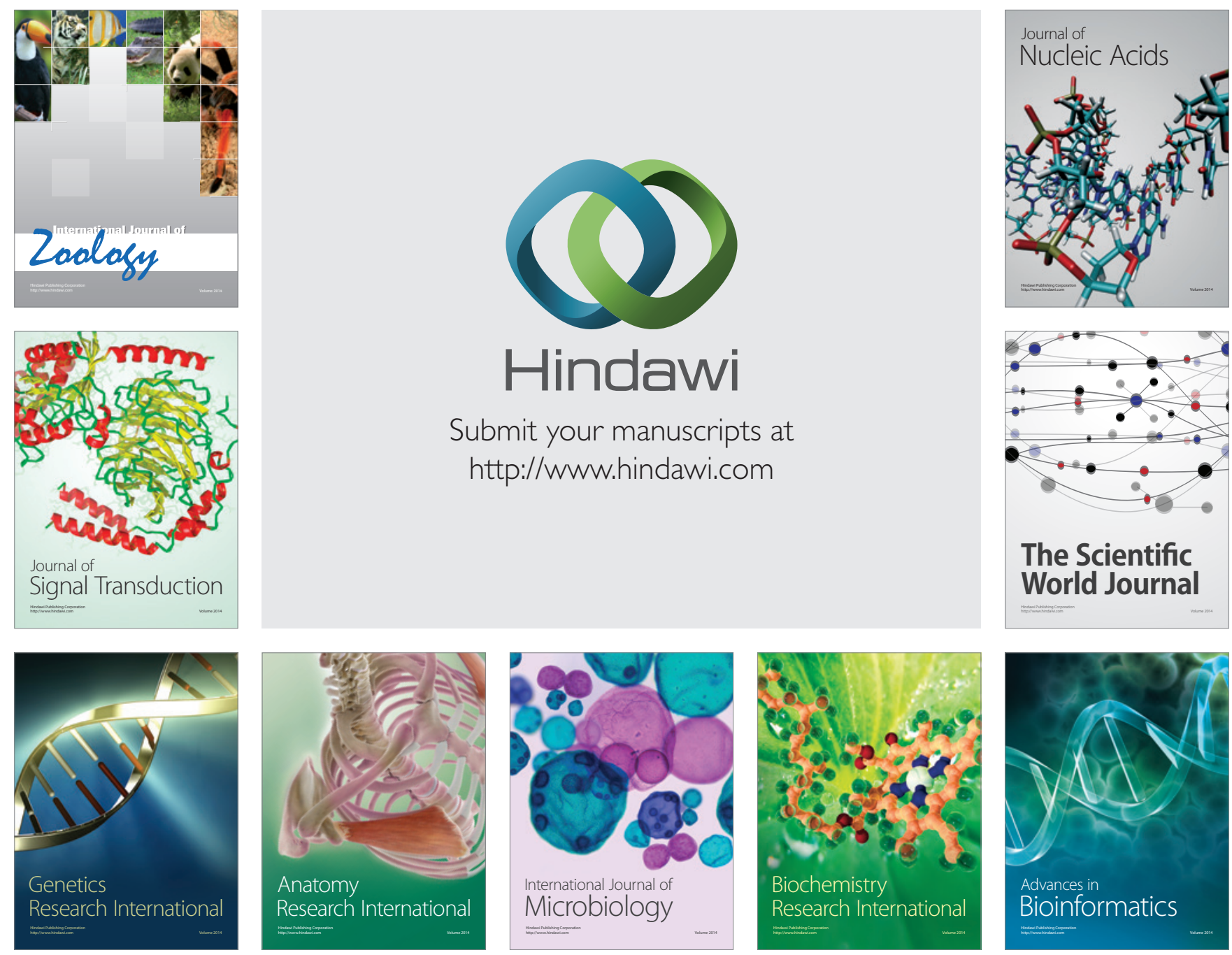

The Scientific World Journal
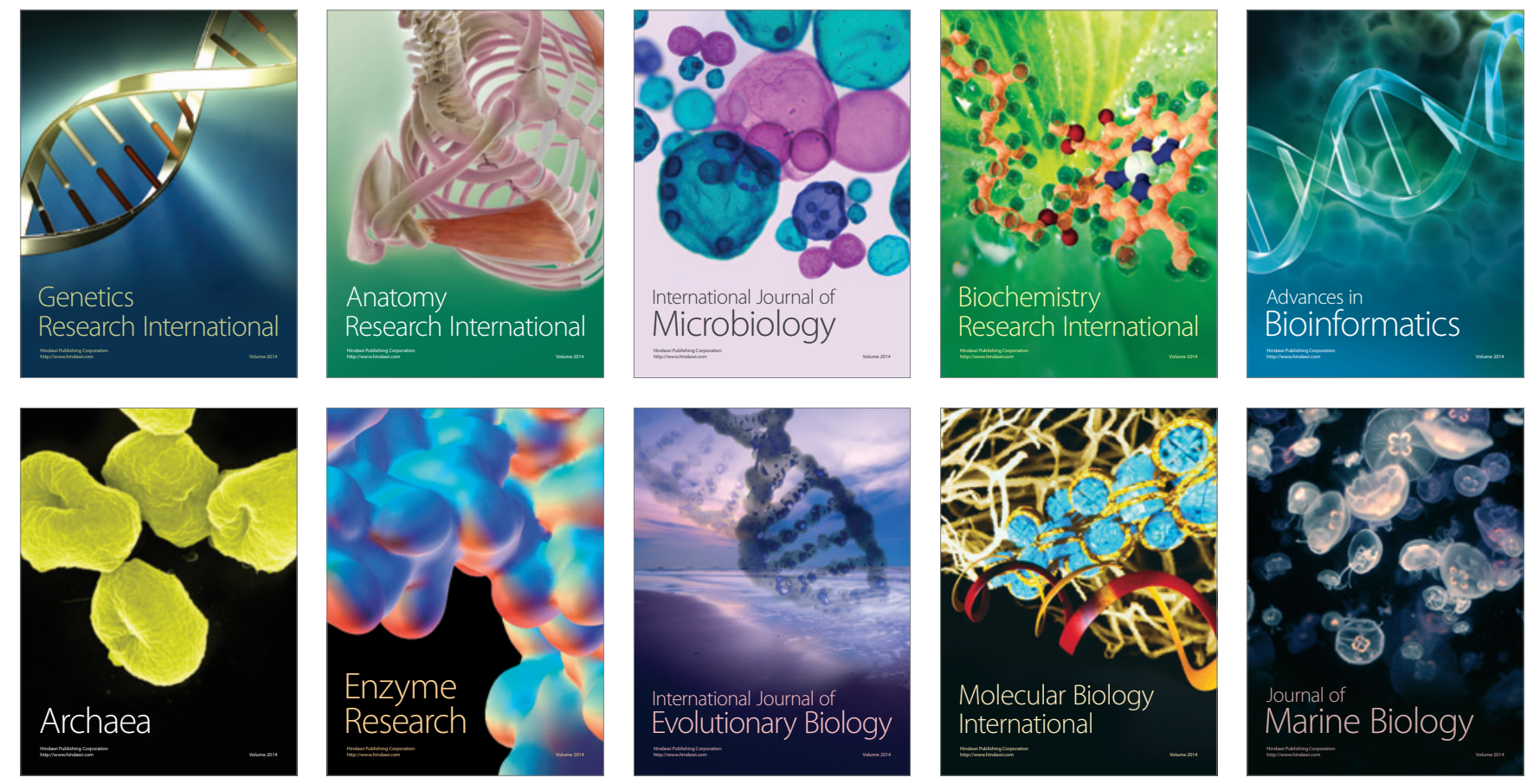